EXTENDED REPORT

\title{
Localised invasive sino-orbital aspergillosis: characteristic features
}

\author{
J A Sivak-Callcott, N Livesley, R A Nugent, S L Rasmussen, P Saeed, J Rootman
}

Br J Ophthalmol 2004;88:681-687. doi: 10.1136/bjo.2003.021725

See end of article for authors' affiliations ......................

Correspondence to: Professor J Rootman, Departments of Ophthalmology \& Pathology, University of British Columbia, 2550 Willow Street, Vancouver, British Columbia, Canada V5Z 3N9; jrootman@ interchange.ubc.ca

Accepted

7 September 2003
Background/aim: To describe the characteristic constellation of historical, clinical, radiographic, and histopathological findings of localised invasive sino-orbital aspergillosis based on the authors' recent experience of four consecutive cases presenting over a 6 month period. Treatment and outcome are reviewed.

Methods: A case series of four patients with review of the English language literature.

Results: There have been 17 reported cases of invasive sino-orbital aspergillosis in healthy individuals over the past 33 years. The authors report four patients who presented during a 6 month period with persistent and significant pain followed by progressive ophthalmic signs-clinical histories reflecting the literature. Similar imaging findings were also noted: focal hypodense areas within apical infiltrates on contrasted computed tomography correspond to abscesses seen at surgery, and sinus obliteration or involvement of the adjacent sinus lining was noted on magnetic resonance imaging. Bone erosion (often focal) was also seen. There is frequently a delay in making the correct diagnosis, and often disease progression occurs despite treatment.

Conclusions: The authors encountered four cases of invasive sino-orbital aspergillosis, three of which occurred in otherwise healthy individuals. The clinician must be aware of the characteristic presentation so that earlier diagnosis, management, and improved outcomes can be achieved. l: nvasive sino-orbital aspergillosis in healthy patients is rare, with only 17 cases found in the English literature since

1966. Aspergillosis often presents with vague complaints and the absence of clinical findings, making diagnosis difficult. Subsequently, treatment can be delayed or inappropriate thereby accelerating the disease.

In this report, we present four recent patients with localised invasive orbital aspergillosis whose symptoms began between April and September 1999. We outline the constellation of historical, clinical, radiographic, and histopathological findings based on our experience. Three cases are discussed in detail and all are summarised within the context of the literature.

\section{CASE REPORTS}

\section{Case 1}

A 69 year old healthy white male presented with a four week history of sharp, intermittent, left lateral pain radiating to the back of his head and progressing from once a day to continuous. In August 1999, his vision decreased to 20/30 and he noted pain on eye movement and chewing. Despite a normal erythrocyte sedimentation rate, he was diagnosed with temporal arteritis and treated with prednisone $80 \mathrm{mg}$ per day, increased to $100 \mathrm{mg}$ daily in a week when his vision decreased to 20/40. Over the next five days, his vision deteriorated to bare light perception so he was referred to the Orbit Clinic.

Vision was count fingers three feet right and no light perception left, with a $2.2 \mathrm{log}$ unit left relative afferent pupillary defect. Exophthalmometry (Hertel) was $17 \mathrm{~mm}$ bilaterally with full extraocular movements, left palpebral fissure was slightly narrowed, and facial sensation intact. There was a right macular disciform scar and left macular epiretinal membrane. He had diet controlled type 2 diabetes and on admission was hyperglycaemic with a weight loss of 20 pounds over one month.
Computed tomography (CT) showed a focal inhomogeneous mass extending from the left sphenoid sinus into the orbital apex and pterygopalatine fossa (fig 1A). Magnetic resonance imaging (MRI) showed involvement of the ethmoid sinus lining with enhancement, extension into the anterior cavernous sinus (fig $1 \mathrm{~B}$ ), and invasion into the vidian canal with optic nerve sheath enhancement.

He underwent medial orbital biopsy where a small focal abscess with surrounding granular tissue was noted. Fungal organisms were seen on frozen section and Aspergillus fumigatus grown in culture. Permanent sections showed both vascular and bony fungal invasion (fig $1 \mathrm{E}-\mathrm{G}$ ).

Prednisone was discontinued and intravenous amphotericin B with insulin started. He underwent debridement, including removal of the medial rectus muscle, adjacent soft tissue, ethmoid sinuses, and sphenoid sinus mucosa with catheter placement for local irrigation with amphotericin B.

Despite treatment, he developed a complete ptosis and total ophthalmoplegia. Weekly CT showed further enlargement with involvement of the superior and inferior orbital fissures, infratemporal fossa, and intracavernous third nerve (fig IC). The mass stabilised by the fifth week and he was discharged after 6 weeks on oral itraconazole $200 \mathrm{mg}$ twice a day and insulin. His ocular and imaging findings remained unchanged 8 weeks after discharge so itraconazole was discontinued. In February 2000 he developed a tremor and a month later was admitted for decreased mental status. Computed tomography showed further enlargement of the lesion, development of a brain abscess, and temporal lobe and basal ganglia oedema-features consistent with a middle cerebral artery stroke (fig 1D). The patient died 9 months after initial symptoms.

Abbreviations: $\mathrm{CT}$, computed tomography; MRI, magnetic resonance imaging. 

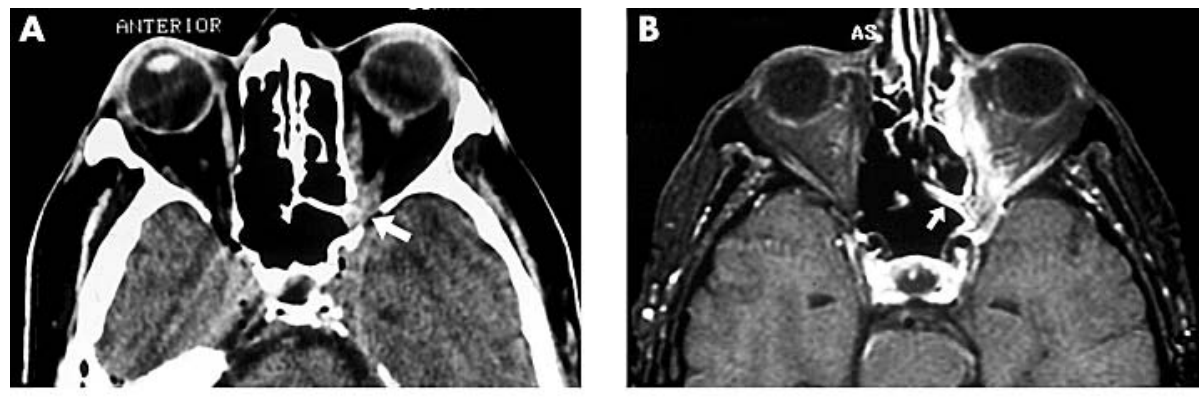

Figure 1 Case 1. (A) Axial computed tomography (CT) shows lesion located in the left apical orbit (arrow), and (B) axial TI weighted MRI with gadolinium and fat suppression performed 1 week later shows the focal sinus lining enhancement (arrow) and extension of the lesion into adjacent tissue. (C) Axial CT 6 weeks after presentation shows stabilisation of the mass. Seven months after initial presentation, repeat CT (D) shows increase in size of the lesion and the presence of a brain abscess in the left temporal lobe (arrow). (E) Grocott
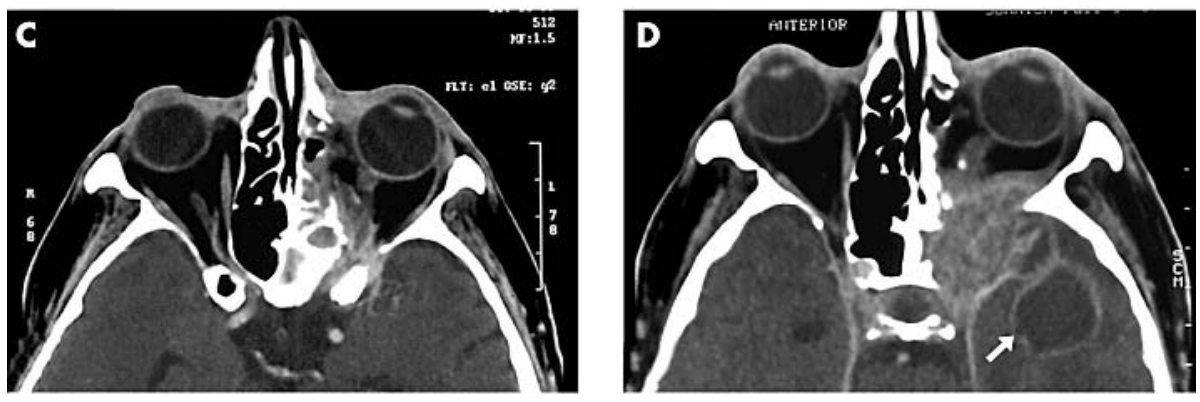
stain of aspergillus organism (original magnification $\times 250)$. (F) Vascular invasion (haematoxylin eosin, original magnification $\times 100$ ). (G) Bony invasion by aspergillus organisms (arrows) (haematoxylin eosin, original magnification $\times 100$ ).
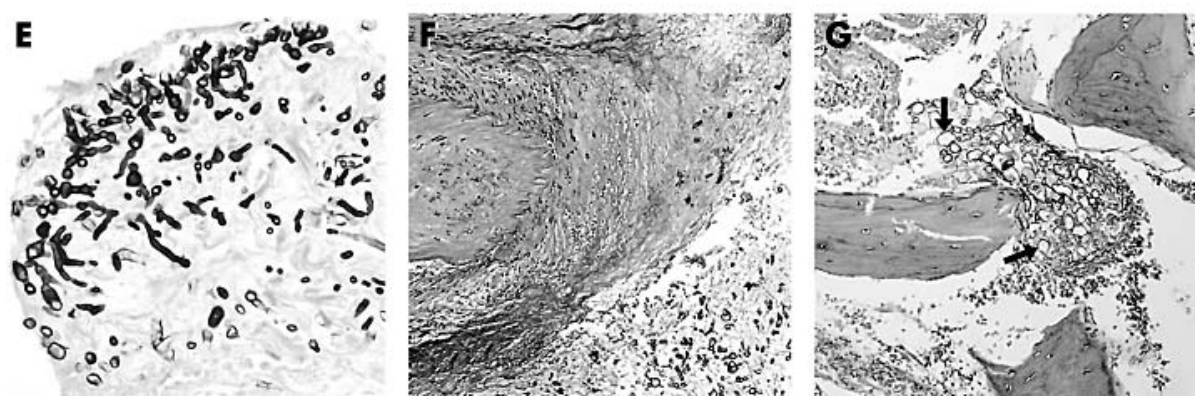

\section{Case 2}

In April 1999, a 77 year old healthy white male developed a daily, intermittent, dull, "toothache like" pain in the right fronto-temporal-parietal region, initially relieved by acetaminophen. By June, he had right periorbital oedema without injection and worsening of pain, which failed to respond to both carbamazepine (Tegretol, Novartis Pharmaceuticals Canada Inc, Dorval, Quebec, Canada) and amitriptyline hydrochloride (Elavil, Merck-Frosst Canada Ltd, Kirkland, Quebec, Canada). A diagnosis of temporal arteritis was entertained but discarded because of lack of other symptoms and an erythrocyte sedimentation rate of 5. By August, the pain was constant with persistent oedema and he developed intermittent diplopia on side gaze. Computed tomography showed a soft tissue lesion in the right lateral sphenoid sinus and orbital apex (fig 2A). Repeat scans (September) showed enlargement of the lesion and involvement of the pterygopalatine fossa, infraorbital fissure, and anterior cavernous sinus. There was a $10 \times 8 \mathrm{~mm}$ low density area at the orbital apex with focal bony destruction of the sphenoid sinus wall and widening of the superior and inferior orbital fissures (fig 2B).

On referral, his vision was 20/25+3 right and 20/20 left with $2 \mathrm{~mm}$ of right ptosis. The remainder of his exam was normal, but past medical history was remarkable for hypertension, peptic ulcer in 1975, osteoarthritis, and excision without recurrence of a preauricular basal cell carcinoma. He was not on any medication.

An apical biopsy revealed a small focal abscess with surrounding granular tissue extending through the bone into the sphenoid and ethmoid sinuses anterior to the optic canal, which corresponded to the focal low density area on CT.

Tissue was removed from the sphenoid and ethmoid sinuses and nasal turbinate, and an irrigating catheter left in place. On histopathology, fungal hyphae invaded the bone of the sphenoid and ethmoid sinuses, and Aspergillus fumigatus was grown in culture. Other laboratory testing, including HIV, was normal.

Despite immediate treatment with local and intravenous amphotericin B, his vision declined to no light perception over one week. Two weeks after starting amphotericin B, he was switched to oral itraconazole for 12 weeks because of increased creatinine levels. Thirteen months after initial onset, his vision had improved to count fingers, and there has been no growth of the mass (figs $2 \mathrm{C}$ and $\mathrm{D}$ ).

\section{Case 3}

In September 1999, a 73 year old white female developed vague, dull, right retrobulbar pain that, by January, had a sharp, stabbing component, slightly eased with Zoloft (sertraline hydrochloride). Two months later, she developed a right sixth nerve palsy, decreased sensation in $\mathrm{Vl}$ distribution, ptosis, limitation on upgaze, dilated pupil, and $2 \mathrm{~mm}$ of proptosis. Computed tomography showed a homogeneous soft tissue mass in the orbital apex extending into the anterior cavernous sinus with a small bony defect in the wall of the sphenoid sinus (fig 3A). MRI a month later showed an enhancing lesion in the right orbital apex and cavernous sinus with bony sclerosis of the right lateral sphenoid sinus and clinoid with focal mucosal enhancement (fig 3B). Nine months after onset, right vision decreased and she was referred.

Visual acuity was 20/60 right and 20/20 left with right decreased colour vision and poor pupillary reaction. She had 

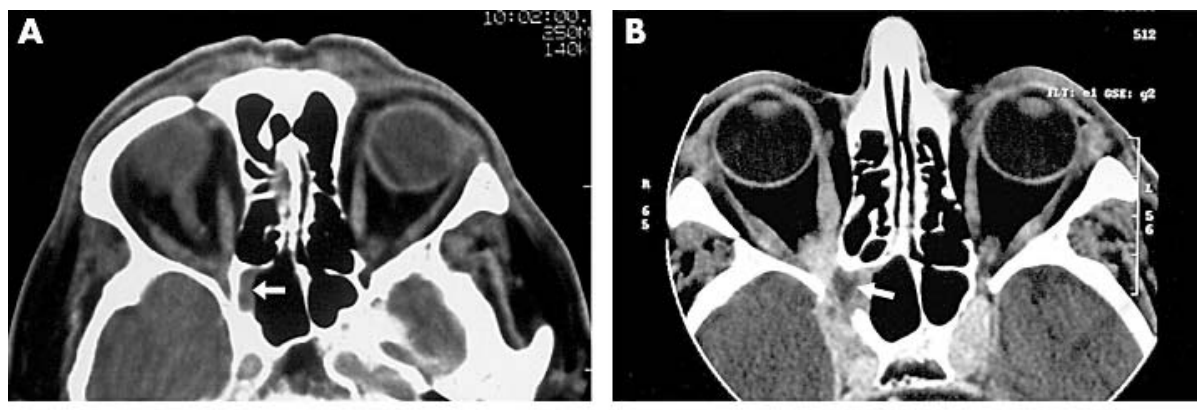

Figure 2 Case 2. (A) Axial computed tomography (CT) before referral shows sphenoid sinus (arrow)/orbital apical lesion. (B) Axial CT performed 4 months later shows enlargement of the lesion with a focal low density abscess (arrow). (C) Axial and (D) coronal scans performed 8 months after diagnosis shows stabilisation of the lesion.
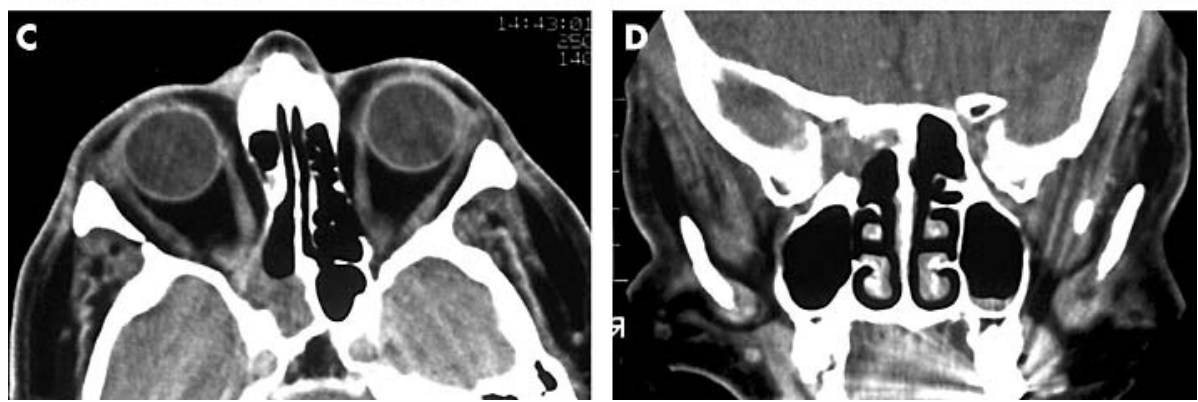

$6 \mathrm{~mm}$ of ptosis, $5 \mathrm{~mm}$ proptosis, decreased motility in all directions, slight right upper lid erythema, intraocular pressures of $19 \mathrm{~mm} \mathrm{Hg}$ right and $14 \mathrm{~mm} \mathrm{Hg}$ left, mild, diffuse conjunctival injection, and temporal pallor of the optic nerve. The rest of the examination and laboratory values were normal, and past history was non-contributory.
Histopathology showed dense fibrous tissue with minimal inflammation, normal optic nerve sheath, and normal orbital fat, consistent with the tissue appearance at the time of surgery. The patient began a four week trial of prednisone $40 \mathrm{mg}$ per day, during which time her vision decreased to no light perception. She furthermore developed a complete
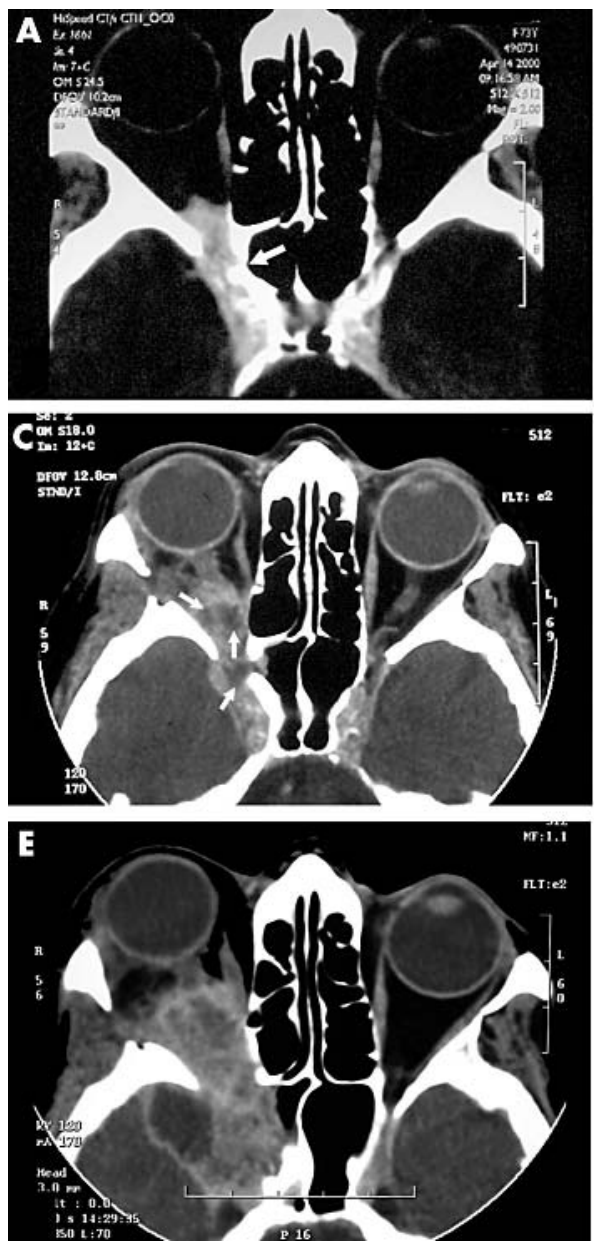

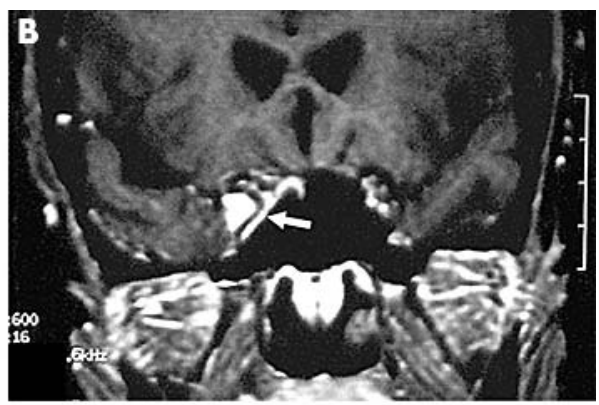

Figure 3 Case 3. (A) An apical lesion can be seen on axial computed tomography (CT). Note the bony defect in the sphenoid sinus (arrow). (B)

Coronal Tl weighted MRI performed 1 month later shows focal sphenoid sinus lining enhancement (arrow). (C) Axial CT before biopsy shows that the lesion has enlarged in size. Focal abscesses (arrows) can also be noted. Two months after diagnosis, follow up $C T$ (D) shows further enlargement of lesion and 6 months later, a brain

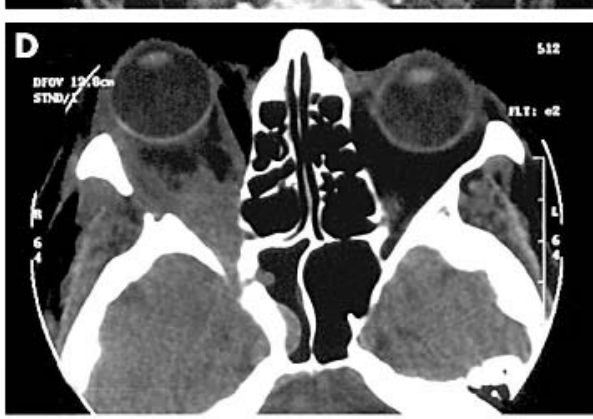
abscess was noted (E). 
ptosis and ophthalmoplegia with worsening of the pain. Repeat CT showed that the mass had become enlarged, expanding the cavernous sinus and extending into the right inferior orbital fissure. Round areas with rim enhancement were noted along with lower density centres (fig 3C).

Because of her deteriorating condition and a diagnosis not yet established, a repeat biopsy was performed. A small abscess with surrounding greyish yellow granular tissue was seen in the orbital apex. Frozen section showed multiple hyphae, later identified as Aspergillus fumigatus in culture. Histology showed the organism to invade bone.

In the first week on intravenous amphotericin B, proptosis, lid injection, and pain improved but worsened the following week. Repeat CT showed an increase in the sphenoid sinus lesion with a larger bony defect and an additional defect in the orbital roof. The mass extended further into the inferior orbital fissure and temporalis fossa, and the extraocular muscles were enlarged.

The option of extensive surgical resection, including removal of the cavernous sinus and intracavernous carotid artery, was considered but rejected because of the high risk and the patient's wishes. Because of rising creatinine levels, she was started on liposomal amphotericin B and rifampin, which was discontinued after two weeks. She remained on liposomal amphotericin B for 10 weeks for a total of $21.0 \mathrm{~g}$. Her pain lessened to tolerable levels but the lesion continued to enlarge (fig 3D) so she was switched to itraconazole and eventually discharged from hospital. In March 2001, her mental state deteriorated, and repeat CT revealed further enlargement with a brain abscess (fig 3E). The patient died 18 months after initial complaint.

Our final case seen during the same time was also characterised by intensifying pain, posterior infiltration of the orbit and adjacent sinuses, focal abscess, and bone destruction followed by relentless progression and death in spite of antifungal therapy and radical exenteration of the orbit, anterior cavernous sinus, adjacent sphenoid, ethmoid, and maxillary sinuses, and portions of the middle cranial fossa. He also had delay based on a primary negative biopsy, requiring a second.

\section{DISCUSSION}

Aspergillus fumigatus infection of the sinuses and orbit can either be non-invasive or invasive. Non-invasive infections are either allergic sinusitis or sinonasal fungal ball wherein destruction of the sinus mucosa and bony expansion may occur but with no invasion of tissue or bone. Invasive infections are either localised or fulminant. Localised disease often starts in the sinuses and spreads to adjacent structures through focal bony erosion or even through vessel walls, causing stroke and death. The fulminant form is characterised by multiple organ involvement. ${ }^{1}$ In our series, all patients had localised, invasive sino-orbital aspergillosis.

Invasive aspergillosis is well documented in immunocompromised patients, with the primary risk factors being neutrophil defects and corticosteroid use. ${ }^{1}$ Other predisposing factors include HIV infection, diabetes mellitus, use of prosthetic devices or trauma, excessive environmental exposure, and possibly advanced age. ${ }^{1}$ Rarely has invasive aspergillus infection been described in immunocompetent patients (table 1). Three of our patients were immunocompetent when they contracted their disease but two had steroids before the diagnosis was made. Case 1 had diet controlled diabetes type 2 requiring insulin on admission, secondary to steroid treatment.

There are 17 similar cases in the English literature over 33 years (table 1). Yet we have seen four cases, all whose symptoms began over a six month period between April and
September 1999. In our community, there has also been a parallel increase of pulmonary aspergillosis.

All of our patients presented with a vague but persistent complaint of pain localised to one side of the head or retrobulbar area. Two had a dull pain that became sharp, whereas the other two began with sharp, stabbing pain. In all, the pain preceded the ophthalmic findings by $1-6$ months and became relentless and severe. In the literature, 13 of 17 patients had an initial complaint of pain or headache (table 1$).^{2-12}$

The time from onset of symptoms to diagnosis was 210 months in our patients. In two patients, a diagnosis of temporal arteritis was either made or entertained because of their history of pain. Cases 1 and 3 were treated with steroids, which may worsen aspergillosis infection. In the literature, four cases were diagnosed with temporal arteritis ${ }^{2} 5^{13}$ and eight treated with steroids. ${ }^{2}{ }^{569-11} 13$ A history of persistent unilateral pain, without other findings, that becomes sharp, relentless, and severe should alert the clinician to the possibility of orbital aspergillosis.

Imaging was similar in these cases with initial studies showing a focal soft tissue lesion; in three, this first involved the sphenoid sinus and orbit with a characteristic and subtle focal bony destruction (figs $1 \mathrm{~A}, 2 \mathrm{~A}$, and $3 \mathrm{~A}$ ). It is probable that the infection arises in the sphenoid sinus and spreads to the orbit, which is consistent with the history of pain that precedes ophthalmic/orbital presentation. Of note is that imaging findings may be subtle, thus specific assessment of the sphenoid sinus is required and may be best seen on MRI with focal enhancement of the lining (figs 1 and 3). With progression, focal hypodense areas appear on contrasted CT (figs $2 \mathrm{~B}$ and $3 \mathrm{C}$ ), corresponding to abscesses.

Biopsy is necessary and must be from these focal hypodense areas. The diagnosis can still be difficult to make, as was noted in two patients who required repeat biopsies. Mauriello et $a l^{8}$ Austin et $a l_{,}{ }^{2}$ and Heier et $a l^{14}$ reported patients that required a second biopsy, and there are cases where the diagnosis was made at autopsy. ${ }^{5}{ }^{71}$ If diagnosis is not made on first biopsy and aspergillus suspected, a second biopsy should be performed, especially before considering treatment with corticosteroids.

The aspergillus organism has a characteristic microscopic appearance but culture is the gold standard for identification. This fungus is haemotoxophilic with $45^{\circ}$ branching septate hyphae that are $2-4 \mu \mathrm{m}$ wide, best seen on Gomori methanamine silver and periodic acid Schiff stains. ${ }^{15}$ Because other fungi can be pathologically indistinguishable and require different treatment, all specimens should be sent for culture. Aspergillus incubated on fungal medium at $30^{\circ} \mathrm{C}$ in $45 \%$ humidity will grow in 2-6 days. Colonial morphology and microscopic examination of sporulating forms allows for precise diagnosis. ${ }^{1}$ In our series, the organisms were all identified as fumigatus and seen to invade bone and blood vessel walls, accounting for the manifestations of vascular occlusion and bone destruction (fig lG).

The characteristic predilection for the sphenoid sinus in localised form and the invasive nature is poorly understood. An active man can inhale as many as $5.7 \times 10^{7}$ aspergillus spores in a day, ${ }^{16}$ yet the incidence of disease is low. Over $90 \%$ of North American cases are caused by Aspergillus fumigatus even though it comprises only $0.3 \%$ of the total aerial aspergillus spore count. ${ }^{17}$ Of the strains of aspergillus, only those able to grow at $37^{\circ} \mathrm{C}$ are pathogenic..$^{17-19}$ It is thought that infection occurs when the sinuses are unable to drain, perhaps causing a lower oxygen tension environment. ${ }^{20}$ It may also be that the oxygen tension or local metabolic environment in the sphenoid sinus is different than other sinuses. Aspergillus fumigatus and, to a lesser extent, A flavus are able to bind laminin and fibrinogen, which may allow for 


\begin{tabular}{|c|c|c|c|c|c|c|c|}
\hline Case & $\begin{array}{l}\text { Age } \\
\text { (years), } \\
\text { sex }\end{array}$ & $\begin{array}{l}\text { Initial } \\
\text { complaint }\end{array}$ & $\begin{array}{l}\text { Had } \\
\text { temporal } \\
\text { arteritis? }\end{array}$ & $\begin{array}{l}\text { Treated } \\
\text { with } \\
\text { steroids? }\end{array}$ & Other treatment & Outcome* & $\begin{array}{l}\text { Start in } \\
\text { sphenoid } t\end{array}$ \\
\hline $\begin{array}{l}\text { Green et al, } \\
1969 \text { (case 3) }\end{array}$ & 71 , male & Pain & & & Not reported & $\begin{array}{l}\text { Dead } \\
8 \text { months } \\
\text { later }\end{array}$ & \\
\hline $\begin{array}{l}\text { Green et al, } \\
1969 \text { (case 6) }\end{array}$ & 84 , male & Pain & Yes & Yes & Not reported & $\begin{array}{l}\text { Dead } \\
6 \text { weeks later }\end{array}$ & \\
\hline $\begin{array}{l}\text { Green et al, } \\
1969 \text { (case 10) } \\
\text { (identified as } \\
\text { Aspergillus } \\
\text { species) }\end{array}$ & 50 , female & Pain & & & $\begin{array}{l}\text { Debridement; } \\
\text { amphotericin B }\end{array}$ & $\begin{array}{l}\text { Dead } \\
16 \text { months } \\
\text { later }\end{array}$ & \\
\hline $\begin{array}{l}\text { Hedges \& } \\
\text { Leung, } 1976\end{array}$ & 62 , female & $\begin{array}{l}\text { Headache } \\
\text { then severe } \\
\text { pain }\end{array}$ & & Yes & $\begin{array}{l}\text { Debridement and } \\
\text { amphotericin B }\end{array}$ & $\begin{array}{l}\text { Dead } \\
5 \text { months } \\
\text { later }\end{array}$ & \\
\hline Yu et al, 1980 & 37 , male & Pain & & & $\begin{array}{l}\text { Surgery; } \\
\text { amphotericin B; } \\
\text { rifampin; } \\
\text { flucytosine }\end{array}$ & $\begin{array}{l}\text { Alive at } 1 \\
\text { year }\end{array}$ & \\
\hline $\begin{array}{l}\text { Spoor et al, } \\
1982\end{array}$ & 49 , female & Pain & & Yes & $\begin{array}{l}\text { Amphotericin B } \\
\text { and rifampin }\end{array}$ & $\begin{array}{l}\text { Dead } \\
2 \text { months }\end{array}$ & Yes \\
\hline $\begin{array}{l}\text { Austin et al, } \\
1983\end{array}$ & 77 , male & Pain & Yes & Yes & $\begin{array}{l}\text { Debridement; } \\
\text { amphotericin B }\end{array}$ & $\begin{array}{l}\text { Dead } \\
11 \text { months } \\
\text { later }\end{array}$ & \\
\hline $\begin{array}{l}\text { Fuchs et al, } \\
1985\end{array}$ & 48 , female & Pain & & & $\begin{array}{l}\text { Surgery; } \\
\text { amphotericin B; } \\
\text { rifampin }\end{array}$ & $\begin{array}{l}\text { Alive at } \\
\text { Imonth }\end{array}$ & Yes \\
\hline $\begin{array}{l}\text { Lowe \& Bradley, } \\
1986\end{array}$ & 74, female & Headache & & & None & $\begin{array}{l}\text { Dead } \\
12 \text { months } \\
\text { later }\end{array}$ & \\
\hline $\begin{array}{l}\text { Bradley et al, } \\
1987\end{array}$ & 74 , female & Pain & Yes & Yes & $\begin{array}{l}\text { Amphotericin B; } \\
\text { flucytosine; } \\
\text { ketoconazole; } \\
\text { vibunazole }\end{array}$ & $\begin{array}{l}\text { Stable at } 2 \\
\text { years }\end{array}$ & \\
\hline Slavin, 1991 & 65 , male & $\begin{array}{l}\text { Left sided } \\
\text { headache then } \\
\text { severe pain }\end{array}$ & & Yes & Amphotericin B & $\begin{array}{l}\text { Dead } \\
2 \text { months } \\
\text { later }\end{array}$ & Yes \\
\hline $\begin{array}{l}\text { Heier et al, } \\
1994 \text { (case 3) }\end{array}$ & 21 , female & $\begin{array}{l}\text { Painless } \\
\text { proptosis }\end{array}$ & & & Amphotericin B & $\begin{array}{l}\text { Alive at } \\
6 \text { months }\end{array}$ & \\
\hline $\begin{array}{l}\text { Mauriello et al, } \\
1995 \text { (case 5) }\end{array}$ & 71 , female & Pain & & & $\begin{array}{l}\text { Debridement; } \\
\text { amphotericin B } \\
\text { then liposomal } \\
\text { amphotericin B; } \\
\text { local } \\
\text { amphotericin B }\end{array}$ & $\begin{array}{l}\text { Dead } \\
4 \text { months } \\
\text { later }\end{array}$ & \\
\hline $\begin{array}{l}\text { Suzuki et al, } \\
1995\end{array}$ & 83 , female & Headache & & Yes & None & $\begin{array}{l}\text { Dead } \\
6 \text { months } \\
\text { later }\end{array}$ & \\
\hline $\begin{array}{l}\text { Massry ef al, } \\
1996\end{array}$ & 40 , female & $\begin{array}{l}\text { Nasal } \\
\text { congestion }\end{array}$ & & & $\begin{array}{l}\text { Debridement; } \\
\text { amphotericin B; } \\
\text { itraconazole }\end{array}$ & $\begin{array}{l}\text { Stable at } 10 \\
\text { years }\end{array}$ & \\
\hline $\begin{array}{l}\text { Hutnik et al, } \\
1997\end{array}$ & 75 , male & $\begin{array}{l}\text { Decreased } \\
\text { vision }\end{array}$ & \multirow{2}{*}{\multicolumn{2}{|c|}{$\begin{array}{l}\text { Yes, despite Yes } \\
\text { negative } \\
\text { biopsy }\end{array}$}} & $\begin{array}{l}\text { Amphotericin B } \\
\text { and fluconazole }\end{array}$ & $\begin{array}{l}\text { Dead } \\
2 \text { months } \\
\text { later }\end{array}$ & Yes \\
\hline $\begin{array}{l}\text { Streppel et al, } \\
1999\end{array}$ & 50 , female & $\begin{array}{l}\text { "Acute } \\
\text { sinusitis" }\end{array}$ & & & $\begin{array}{l}\text { Amphotericin B; } \\
\text { debridement; } \\
\text { liposomal } \\
\text { amphotericin B; } \\
\text { Postoperative } \\
\text { itraconazole }\end{array}$ & $\begin{array}{l}\text { Dead } \\
16 \text { months } \\
\text { later }\end{array}$ & \\
\hline $\begin{array}{l}\text { *Time to death is } \\
\text { or not enough i } \\
\text { †Recorded as " } \\
\text { involved, the ref }\end{array}$ & $\begin{array}{l}\text { s approximat } \\
\text { information o } \\
\text { 'yes" if comp } \\
\text { ference was }\end{array}$ & $\begin{array}{l}\text { ted from initial c } \\
\text { given, the case } \\
\text { puted tomograp } \\
\text { not categorised }\end{array}$ & $\begin{array}{l}\text { complaint } \\
\text { was not i } \\
\text { phy or spe } \\
\text { d as havin }\end{array}$ & $\begin{array}{l}\text { om inforn } \\
\text { luded in } \\
\text { fic descri } \\
\text { glesion }\end{array}$ & $\begin{array}{l}\text { in the case repor } \\
\text { able. } \\
\text { in reference give } \\
\text { started in the sphe }\end{array}$ & $\begin{array}{l}\text { its. If there was } \\
\text { en. If more thar } \\
\text { enoid sinus. }\end{array}$ & $\begin{array}{l}\text { s no follow up } \\
\text { an one site }\end{array}$ \\
\hline
\end{tabular}

tissue invasion. ${ }^{21}$ In addition, other putative virulence factors, such as elastase, catalase, gliotoxin (a phagocyte inhibitor), and ribotoxins, show in vitro activity but what role these play in vivo is unknown. ${ }^{21}$

The prognosis of invasive sino-orbital aspergillosis in immunocompetent patients is significantly worse than the prognosis of other forms of sinus aspergillosis, ${ }^{22}{ }^{23}$ likely because of penetration of bone and blood vessel walls, which often cannot be eradicated by surgery given the anatomic location where drug penetration may also be worse. Only one of our four cases and five of the 17 cases $^{34121424}$ in the literature (one with only 1 month follow up) survived. Of the latter group, one was over the age of 60 , having also been treated with steroids before diagnosis. ${ }^{3}$ Despite treatment, many patients die 2-16 months from initial complaint (table 1).

There is no uniformly accepted, completely effective treatment. Management often begins with surgical debridement and amphotericin B local irrigation followed by a systemic antifungal drug-usually intravenous amphotericin 
Differential diagnosis of invasive sino-orbital aspergillosis based on history and examination

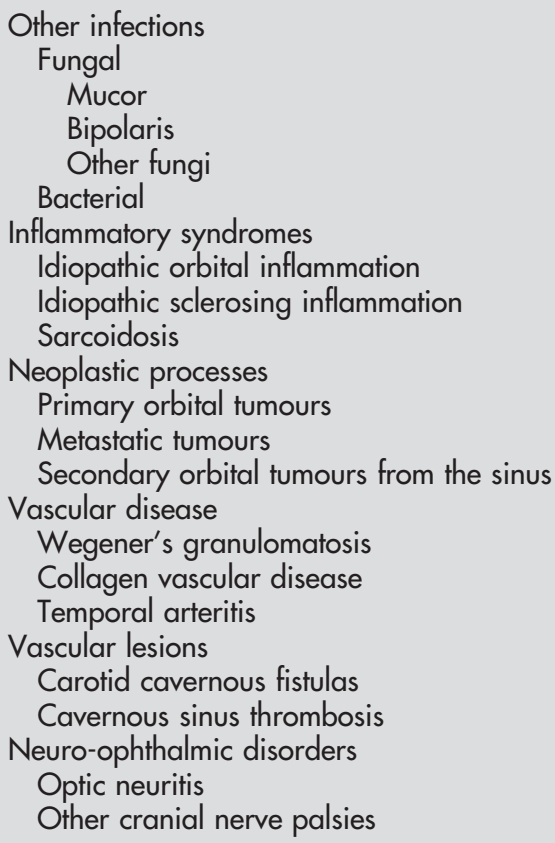

B. There are three types of antifungals used, polyenes (amphotericin), azoles (itraconazole and voriconazole), and other newer experimental classes such as lipid complex nystatin and echinocandins. However, no controlled trials have been done to compare these agents. Data from various sources suggest that response rates of the different drugs are only $40 \%$ to $60 \%$. $^{25}$

Deciding which drug or combination to use is difficult with conflicting reports, but amphotericin B is considered the gold standard based on extensive experience. ${ }^{25}$ Therapy is often prolonged and can be complicated by adverse effects, the most serious of which is renal dysfunction noted in our patients. Newer formulations, including lipid complex and liposomal forms, have been developed to decrease the toxicity of amphotericin B and indeed appear to be less toxic and more efficacious. ${ }^{26}$ Of the azole class, itraconazole and voriconazole are the most promising and are safer and easier to administer than amphotericin. Massry et al ${ }^{24}$ and Streppel et $a l^{27}$ have successfully used itraconazole in patients with sino-orbital aspergillosis, whereas voriconazole has not been assessed in this situation. Combinations of itraconazole and amphotericin have been used but there is in vitro evidence of antagonism. ${ }^{1827}$ Most experts recommend giving the maximum daily dose of the chosen medication and after the disease is controlled, prolonged administration of oral itraconazole to ensure eradication. ${ }^{25}$ Treatment should continue well past any remaining signs of disease and indefinite use considered in patients with ongoing immunosuppression.

Radical surgical debridement of the orbit, adjacent sinuses, and skull base area may be considered but is often complicated by other decision making factors, including patient wishes and difficulty in determining the extent of the lesion.

\section{CONCLUSION}

Localised invasive sino-orbital aspergillosis in healthy patients was thought to be a rare disease, but we have reported four cases that presented within a six month period. These patients have a similar constellation of symptoms and signs, consisting of unilateral facial or retrobulbar pain that eventually becomes sharp, constant, and severe enough to require narcotic analgesics. The pain antecedes ophthalmic signs and is consistent with a lesion arising in the sphenoid sinus, which commonly is the site of origin. This presentation suggests a long differential diagnosis, including other infectious, inflammatory, neoplastic, vascular, and neuroophthalmic disorders (see box). Some of these lead to corticosteroid administration, which worsens aspergillosis infection. Once the infection spreads to the orbit, patients manifest adnexal/orbital signs, often losing all vision over 510 days. In addition, it can invade the cavernous sinus and other contiguous structures, culminating in death.

Neuroimaging shows localised soft tissue densities with bony destruction and often hypodense areas that correspond to focal abscesses with sinus mucosa involvement, particularly noted on MRI. Biopsy of the focal abscess is necessary for diagnosis. Once diagnosis is established, debridement with local irrigation followed by maximal prolonged antifungal therapy is recommended. Awareness of this disease with its characteristic symptoms, signs, and imaging features may lead to earlier diagnosis and treatment, and improved outcome.

\section{Authors' affiliations}

J A Sivak-Callcott, S L Rasmussen, P Saeed, J Rootman, Department of Ophthalmology, University of British Columbia and the Vancouver Hospital \& Health Sciences Centre, Vancouver, British Columbia, Canada

N Livesley, Division of Infectious Disease, Department of Medicine, University of British Columbia and the Vancouver Hospital \& Health Sciences Centre, Vancouver, British Columbia, Canada R A Nugent, Division of Neuroradiology, Department of Radiology, University of British Columbia and the Vancouver Hospital \& Health Sciences Centre, Vancouver, British Columbia, Canada

S L Rasmussen, J Rootman, Department of Pathology, University of British Columbia and the Vancouver Hospital \& Health Sciences Centre, Vancouver, British Columbia, Canada

\section{REFERENCES}

1 Levin LA, Avery R, Shore J, et al. The spectrum of orbital aspergillosis: a clinicopathological review. Surv Ophthalmol 1996;41:142-54.

2 Austin P, Dekker A, Kennerdell JS. Orbital aspergillosis. Report of a case diagnosed by fine needle aspiration biopsy. Acta Cytol 1983:27:166-9.

3 Bradley SF, McGuire NM, Kauffman CA. Sino-orbital and cerebral aspergillosis: cure with medical therapy. Mykosen 1987:30:379-85.

4 Fuchs HA, Evans RM, Gregg CR. Invasive aspergillosis of the sphenoid sinus manifested as a pituitary tumor. South Med J 1985;78:1365-7

5 Green WR, Font RL, Zimmerman LE. Aspergillosis of the orbit. Arch Ophthalmol 1969;82:302-13

6 Hedges TR, Leung LE. Parasellar and orbital apex syndrome caused by aspergillosis. Neurology 1976;26:117-20.

7 Lowe J, Bradley J. Cerebral and orbital aspergillus infection due to invasive aspergillosis of ethmoid sinus. J Clin Pathol 1986;39:774-8.

8 Mauriello JA, Yepez N, Mostafavi R, et al. Invasive rhinosino-orbital aspergillosis with precipitous visual loss. Can J Ophthalmol 1995:30:124-30.

9 Slavin ML. Primary Aspergillosis of the orbital apex. Arch Ophthalmol 1991;109:1502-3.

10 Spoor TC, Hartel WC, Harding S, et al. Aspergillosis presenting as a corticosteroid responsive optic neuropathy. J Clin Neuroophthalmol 1982;2:103-7.

11 Suzuki K, Iwabuchi N, Kuramochi S, et al. Aspergillus aneurysm of the middle cerebral artery causing a fatal subarachnoid hemorrhage. Intern Med 1995:34:550-3.

12 Yu VL, Wagner GE, Shadomy S. Sino-orbital aspergillosis treated with combination antifungal therapy. Successful therapy after failure with amphotericin B and surgery. JAMA 1980;244:814-15.

13 Hutnik CML, Nicolle DA, Munoz DG. Orbital aspergillosis a fatal masquerader. J Neuroophthalmol 1997;17:257-61.

14 Heier JS, Gardner TA, Hawes MJ, et al. Proptosis as the initial presentation of fungal sinusitis in immunocompetent patients. Ophthalmology $1995 ; 102: 713-17$ 
15 Denning DW, Venkateswarlu K, Oakley KL, et al. Itraconazole resistance in aspergillus fumigatus. Antimicrob Agents Chemother 1997;41:1364-8

16 Novey HS, Wells ID. Allergic bronchopulmonary aspergillosis caused by Aspergillus ochraceus. Am J Clin Pathol 1978;70:840-3.

17 Ruchel R, Reichard U. Pathogenesis and clinical presentation of aspergillosis. Contrib Microbiol 1999;2:21-3.

18 Schaffner A, Bohler A. Amphotericin B refractory aspergillosis after itraconazole: evidence for significant antagonism. Mycoses 1993:36:421-4.

19 Schneemann M, Schaffner A. Host defense mechanisms in aspergillus fumigatus infections. Contrib Microbiol 1999;2:57-68.

20 Weber RS, Lopez-Berestein G. Treatment of invasive Aspergillus sinusitis with liposomal-amphotericin B. Laryngoscope 1987;97:937-41.

21 Hogan LH, Klein BS, Levitz SM. Virulence factors of medically important fungi. Clin Microbiol Rev 1996;9:469-88.
22 Denning DW, Hanson LH, Perlman AM, et al. In vitro susceptibility and synergy studies of aspergillus species to conventional and new agents. Diagn Microbiol Infect Dis 1992;15:21-34.

23 Denning DW. Aspergillus species. In: Mandell GL, Bennett JE, Dolin R, eds. Principles and Practice of Infectious Diseases. 5th ed. Philadelphia: Churchill Livingstone, 2000;2:2674-85.

24 Massry GG, Hornblass A, Harrison W. Itraconazole in the treatment of orbital aspergillosis. Ophthalmology 1996;103:1467-70.

25 Stevens DA, Kan VL, Judson MA. Practice guidelines for disease caused by aspergillus. Clin Infect Dis 2000;30:696-709.

26 Walsh TJ, Finberg RW, Arndt C. Liposomal amphotericin B for empirical therapy in patients with persistent fever and neutropenia. N Engl J Med 1999;340:764-71.

27 Streppel M, Bachmann G, Damm M, et al. Successful treatment of an invasive aspergillosis of the skull base and paranasal sinuses with liposomal amphotericin B and itraconazole. Ann Otol Rhinol Laryngol 1999; 108:205-7. 